\title{
Clustering Data Polutan Udara Kota Pekanbaru dengan Menggunakan Metode K-Means Clustering
}

\author{
Fathuddin Yazid $^{1}$, Muhammad Affandes ${ }^{2}$ \\ ${ }^{1,2}$ Teknik Informatika UIN Sultan Syarif Kasim Riau \\ Jl. H.R. Soebrantas no. 155 KM. 18 Simpang Baru, Pekanbaru 28293 \\ fathuddinyazid@gmail.com ${ }^{1}$, affandes@uin-suska.ac.id ${ }^{2}$
}

\begin{abstract}
Abstrak - Pencemaran udara adalah salah satu permasalahan yang selalu mengganggu kesehatan lingkungan, seperti kabut asap yang belakangan ini terjadi setiap tahunnya di wilayah Kota Pekanbaru yang mengganggu kesehatan manusia bahkan sampai menelan korban jiwa. Untuk itu diterapkan ilmu dari data mining dengan metode $K$-means clustering yang dapat mengelompokkan polutan pencemar udara. Pengelompokan cluster dilakukan dengan beberapa kali pengujian dengan jumlah cluster berbeda dan juga dengan pengolahan data yang berbeda sebagai perbandingan untuk mencari hasil yang optimal. Setelah kelompok polutan dari 5 cluster di urutkan berdasarkan kadar polutan yang terkandung dapat disimpulkan bahwa polutan mengalami kenaikan antara bulan Juni dan Juli kemudian turun kembali pada bulan Oktober dan November sehingga diharapkan masyarakat lebih waspada pada rentang bulan-bulan tersebut untuk mencegah efek negatif dari polutan udara seperti ispa dan gangguan pernapasan lainnya bahkan dapat menyebabkan kematian.
\end{abstract}

Kata kunci - Clustering, Data mining, K-means, Polutan udara

\section{PENDAHULUAN}

Udara yang bersih merupakan kebutuhan setiap manusia, namun tidak hanya manusia yang membutuhkannya, tumbuhan dan hewan juga membutuhkan udara yang bersih untuk dapat bertahan hidup. Udara yang bersih biasanya terdapat di daerah pedesaan dimana masih banyak dijumpai pepohonan dan selain itu polusi dari asap kendaraan maupun asap dari pabrik masih sangat sedikit, namun berbeda halnya dengan daerah perkotaan dimana seperti yang kita ketahui bersama bahwa udara di daerah perkotaan cenderung lebih kotor dibandingkan dengan udara di wilayah pedesaan, banyaknya jumlah kendaraan di daerah perkotaan serta aktifitas pabrik yang berkontribusi pada pencemaran udara oleh polusi. Namun pencemaran udara tidak selalu berasal dari polusi yang disebabkan oleh mesin kendaraan maupun aktifitas pabrik, pencemaran udara juga dapat disebabkan oleh bencana kemarau panjang dan akan mengakibatkan kebakaran hutan yang asap nya akan membuat udara tercemar seperti yang belakangan ini terjadi tiap tahunnya di wilayah Sumatera khususnya Kota Pekanbaru. Menurut salah seorang ilmuwan Colombia University yang bekerja untuk NASA mengenai bencana di wilayah sumatera dan sekitar tersebut, kondisi di Singapura dan tetangga Sumatera serupa dengan 1997, Jika perkiraan cuaca yang memprediksi kemarau panjang bertahan, ini akan membuat kabut asap 2015 termasuk yang paling parah dalam sejarah [1].

Kesehatan lingkungan adalah suatu keseimbangan ekologi yang harus ada antara manusia dan lingkungan agar dapat menjamin keadaan sehat dari manusia. Apabila kesehatan lingkungan terganggu maka juga akan berpengaruh kepada kesehatan manusia. Seperti yang terjadi di Kota Pekanbaru dimana terjadi kabut asap yang tidak hanya mengganggu kesehatan lingkungan tetapi juga mengganggu kesehatan manusianya, bahkan sampai menelan korban jiwa. Dikutip dari Liputan6.com, Kabut asap di Riau akibat kebakaran hutan dan lahan kembali menelan korban jiwa, Ramadhani Lutfi Aerli (9) menghembuskan napas terakhir pada Rabu (21/10/2015) dini hari akibat gangguan pernapasan. Sebelumnya murid kelas 3 SD di Jalan Sumatera, Pekanbaru, itu sempat dirawat intensif di Rumah Sakit Santa Maria. Sejumlah perawatan medis tak mampu menyelamatkan nyawanya karena paru-parunya sudah dipenuhi asap. Mereka menambahkan meninggalnya Ramadhani kian memperpanjang daftar korban tewas akibat kabut asap. Sebelumnya ada bocah 12 tahun, Muhanum Angriawati dan seorang PNS meninggal karena kabut asap [2]. Selain mengganggu kesehatan, kabut asap di Kota Pekanbaru juga mengganggu proses belajar mengajar, dari mulai tingkat TK sampai tingkat Perguruan Tinggi. Dikutip dari Majalah Lingkungan Hidup Lestari, Menteri Pendidikan, seperti yang dilansir beberapa media massa telah memberikan edaran untuk mengatasi dampak kabut asap bagi dunia pendidikan. Kesehatan serta keselamatan peserta didik dan pendidik adalah prioritas utama. Dan akan diberlakukan perlakuan khusus bagi daerah yang 
terkena dampak kabut asap. Surat edaran Menteri Pendidikan dan Kebudayaan tersebut bertanggal 23 Oktober 2015 dan berisi sembilan poin yang memuat penanganan pada proses belajar mengajar selama dan sesudah kabut asap, salah satunya kebijaksanaan meliburkan siswa dari kegiatan belajar mengajar.

Penelitian terdahulu yang membahas tentang polutan udara yaitu dengan judul Clustering Data Pencemaran Udara Sektor Industri Di Jawa Tengah Dengan Kohonen Neural Network. Hasil clustering pada data beban pencemaran udara sektor industri di Jawa Tengah tahun 2006 yang termasuk Cluster I yaitu industri kecil, yang termasuk Cluster II yaitu industri makanan, industri minuman, industri kimia dasar, industri non logam, industri semen, industri kapur dan gips, industri logam dasar, industri hasilhasil olahan logam, industri rumah sakit, dan industri perhotelan, yang termasuk Cluster III yaitu industri kayu, industri olahan kayu, dan industri kertas [3].

Penelitian berjudul A Cluster Analysis Of Constant Ambient Air Monitoring Data from the Kanto Region of Japan mengcluster stasiun monitoring data wilayah Kanto Jepang berdasarkan 4 polutan yaitu NOx, Ox, NMHC, dan SPM dengan tujuan agar dapat mengurangi jumlah stasiun monitoring yang berada di sekitar wilayah Kanto Jepang. Kesimpulan dari penelitian tersebut yaitu stasiun monitoring di cluster kedalam 8 cluster, dan dapat dikonfirmasi bahwa stasiun monitoring dapat di cluster secara topologi untuk NOx dan Ox menggunakan analisa cluster. Jika stasiun monitoring udara ambien memungkinkan untuk di kelompokkan maka begitu juga dengan mengurangi jumlah stasiun monitoring dapat dimungkinkan dengan melihat beberapa kriteria [4].

Dengan adanya data-data tersebut masyarakat sepatutnya mewaspadai akibat dari masalah polusi udara ini dan tidak meremehkannya, masih banyak di antara masyarakat yang tetap memaksakan diri untuk keluar rumah disaat bencana kabut asap seperti yang telah terjadi, padahal mereka mengetahui bahwa indikator polusi udara yang terpampang di jalan dan juga disebar melalui surat kabar cetak maupun elektronik menyatakan bahwa udara sangatlah tidak sehat dan berbahaya bagi kesehatan. Untuk mewaspadai akibat dari masalah polusi, terlebih dahulu kita harus mengetahui kapan saja kondisi polusi udara berbahaya bagi kesehatan manusia, salah satu caranya yaitu dengan memprediksi dengan melihat pola dari polusi udara yang telah terjadi beberapa tahun terakhir sehingga masyarakat dapat lebih waspada dan dapat mencegah akibat negatif dari polusi udara.

\section{LANDASAN TEORI}

Gas polutan adalah gas-gas yang menyebabkan terjadinya polusi atau pencemaran udara. Gas-gas polutan ini dapat menimbulkan berbagai bibit penyakit bagi semua makhluk hidup baik manusia, hewan dan juga tumbuhan.

\begin{tabular}{|c|c|c|c|c|c|c|}
\hline Kategori & Rentang & $\begin{array}{c}\text { Carbon } \\
\text { Monoksida } \\
\text { (CO) }\end{array}$ & $\begin{array}{l}\text { Nitrogen } \\
\left(\mathrm{NO}_{2)}\right)\end{array}$ & Ozon $\left(\mathrm{O}_{3}\right)$ & $\begin{array}{c}\text { Sulfur } \\
\text { Dioksida } \\
\left(\mathrm{SO}_{2}\right)\end{array}$ & Partikulat \\
\hline Baik & $0-50$ & Tidak ada efek & Sedikit berbau & $\begin{array}{l}\text { Luka pada } \\
\text { beberapa } \\
\text { spesies } \\
\text { tumbuhan } \\
\text { akibat } \\
\text { kombinasi } \\
\text { dengan } \mathrm{SO}_{2} \\
\text { (selama } 4 \text { jam) }\end{array}$ & $\begin{array}{l}\text { Luka pada } \\
\text { beberapa } \\
\text { spesies } \\
\text { tumbuhan } \\
\text { akibat } \\
\text { kombinasi } \\
\text { dengan } \mathrm{O}_{3} \\
\text { (selama } 4 \mathrm{jam} \text { ) }\end{array}$ & Tidak ada efek \\
\hline Sedang & $51-100$ & $\begin{array}{l}\text { Perubahan } \\
\text { kimia } \\
\text { darah tapi } \\
\text { tidak } \\
\text { terdeteksi }\end{array}$ & Berbau & $\begin{array}{l}\text { Luka pada } \\
\text { beberapa } \\
\text { spesies } \\
\text { tumbuhan }\end{array}$ & $\begin{array}{l}\text { Luka pada } \\
\text { beberapa } \\
\text { spesies } \\
\text { tumbuhan }\end{array}$ & $\begin{array}{l}\text { Terjadi } \\
\text { penurunan } \\
\text { pada jarak } \\
\text { pandang }\end{array}$ \\
\hline $\begin{array}{l}\text { Tidak } \\
\text { Sehat }\end{array}$ & $101-199$ & $\begin{array}{l}\text { Peningkatan } \\
\text { pada } \\
\text { kardiovaskular } \\
\text { pada perokok } \\
\text { yang sakit } \\
\text { jantung }\end{array}$ & $\begin{array}{l}\text { Bau dan } \\
\text { kehilangan } \\
\text { warna. } \\
\text { Peningkatan } \\
\text { reaktivitas } \\
\text { pembuluh } \\
\text { tenggorokan } \\
\text { pada } \\
\text { penderita asma }\end{array}$ & $\begin{array}{l}\text { Penurunan } \\
\text { kemampuan } \\
\text { pada atlit yang } \\
\text { berlatih keras }\end{array}$ & $\begin{array}{l}\text { Bau, } \\
\text { meningkatnya } \\
\text { kerusakan } \\
\text { tanaman }\end{array}$ & $\begin{array}{l}\text { Jarak pandang } \\
\text { turun dan } \\
\text { terjadi } \\
\text { pengotoran } \\
\text { debu } \\
\text { dimana-mana }\end{array}$ \\
\hline $\begin{array}{l}\text { Sangat } \\
\text { Tidak } \\
\text { Sehat }\end{array}$ & $200-299$ & $\begin{array}{l}\text { Meningkatnya } \\
\text { kardiovaskular } \\
\text { pada orang } \\
\text { bukan perokok } \\
\text { yang } \\
\text { berpenyakit } \\
\text { jantung, dan } \\
\text { akan tampak } \\
\text { beberapa } \\
\text { kelemahan } \\
\text { yang terlihat } \\
\text { secara nyata }\end{array}$ & $\begin{array}{l}\text { Meningkatnya } \\
\text { sensitivitas } \\
\text { pasien yang } \\
\text { bemenyakit } \\
\text { asma dan } \\
\text { bronhitis }\end{array}$ & $\begin{array}{l}\text { Olah raga } \\
\text { ringan } \\
\text { mengakibatkan } \\
\text { pengaruh } \\
\text { pemafasan } \\
\text { pada pasien } \\
\text { yang } \\
\text { berpenyakit } \\
\text { paru-paru } \\
\text { kronis }\end{array}$ & $\begin{array}{l}\text { Meningkatnya } \\
\text { sensitivitas } \\
\text { pada pasien } \\
\text { bemenyakit } \\
\text { asma dan } \\
\text { bronhitis }\end{array}$ & $\begin{array}{l}\text { Meningkatnya } \\
\text { sensitivitas } \\
\text { pada pasien } \\
\text { berpenyakit } \\
\text { asma dan } \\
\text { bronhitis }\end{array}$ \\
\hline Berbahaya & 300 - lebih & & & opust yang & apar & \\
\hline
\end{tabular}

Gambar 1. Pengaruh untuk setiap parameter pencemar 
Berdasarkan peraturan pemerintah RI No.41 Tahun 1999 mengenai Pengendalian Pencemaran Udara, yang dimaksud dengan pencemaran udara adalah masuknya atau dimasuknya zat, energi dan/atau komponen lain ke dalam udara ambient oleh kegiatan manusia sehingga mutu udara ambient turun sampai ke tingkat tertentu yang menyebabkan udara ambient tidak memenuhi fungsinya.

Data mining maksudnya adalah mengekstrak atau menambang pengetahuan dari sekumpulan data yang sangat banyak. Istilah yang lebih tepat untuk data mining seharusnya knowledge mining from data atau menambang pengetahuan dari data. Banyak istilah lain untuk data mining yang memiliki makna yang sama atau sedikit berbeda seperti knowledge mining from data, knowledge extraction, data/pattern analysis, data archaeology, and data dredging [5].
Algoritma $K$-means merupakan algoritma klasterisasi yang mengelompokkan data berdasarkan titik pusat klaster (centroid) terdekat dengan data. Tujuan dari $K$-means adalah pengelompokkan data dengan memaksimalkan kemiripan data dalam satu klaster dan meminimalkan kemiripan data antar klaster. Ukuran kemiripan yang digunakan dalam klaster adalah fungsi jarak. Sehingga pemaksimalan kemiripan data didapatkan berdasarkan jarak terpendek antara data terhadap titik centroid [6].

Tahap-tahap dari algoritma K-means clustering adalah sebagai berikut [5] :

1. Tentukan jumlah cluster $(k)$ yang diinginkan sebagai input.

2. Tentukan titik pusat cluster/centroid secara acak sebanyak jumlah cluster yang di inginkan dari data yang tersedia.

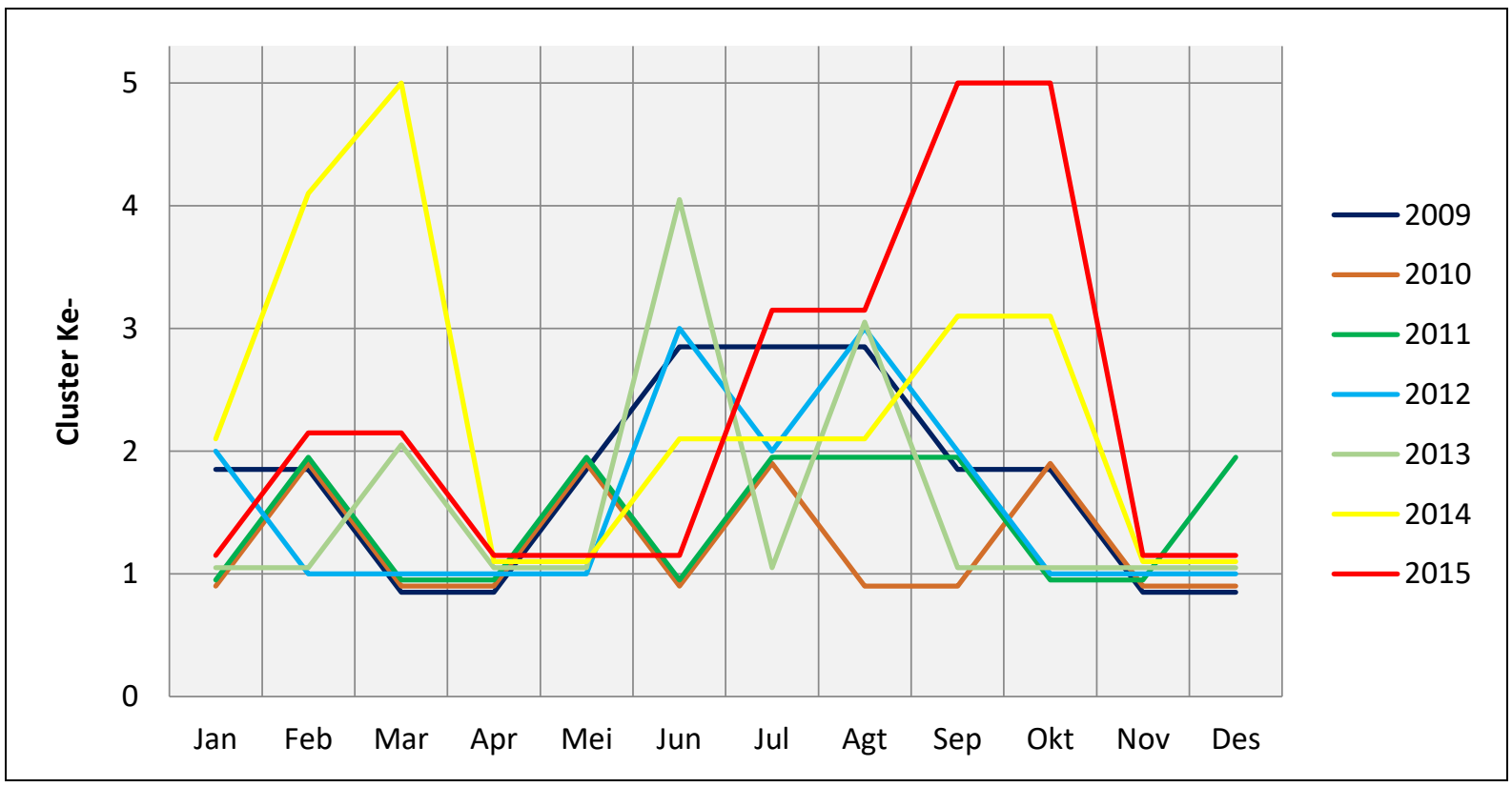

Gambar 2. Kelompok dengan 5 cluster

3. Hitung jarak antara data dengan centroid. Pada penelitian ini menggunakan Euclidean Distance yaitu metode paling popular untuk mencari jarak terpendek antara data dengan centroid dengan rumus yaitu :

Dimana :

$$
\mathrm{D}(\mathrm{X} i, \mathrm{Y} j)=\sqrt{(\mathrm{P} 1 i-\mathrm{Q} 1 j)^{2}}
$$

$\mathrm{D}(\mathrm{Xi}, \mathrm{Yj})=$ Jarak data $i$ ke centroid $j$

$\mathrm{P} 1 i=$ Variabel ke 1 pada data ke $i$

Q1 $j=$ Variabel ke 1 pada centroid $\mathrm{ke} j$

4. Kelompokkan data berdasarkan jarak terpendeknya antara data dengan centroid menjadi sebuah kelompok cluster.

5. Hitung rata-rata tiap kelompok cluster yang terbentuk untuk dijadikan sebagai centroid yang baru dan ulangi perhitungan mencari jarak terpendek antara data dan centroid apabila centroid berubah dan perhitungan akan berhenti apabila centroid tidak mengalami perubahan.

Rapidminer merupakan perangkat lunak yang bersifat opensource. Rapidminer sebelumnya bernama YALE (Yet Another Learning Environment). Rapidminer dikembangkan pada tahun 2001 oleh Ralf Klin Kenberg, Ingo Mierswa dan Simon Fischer dari University of Dortmund ditulis dalam bahasa java. 


\section{METODOLOGI PENELITIAN}

Metodologi penelitian adalah sistematika keseluruhan tahapan yang akan di laksanakan selama penelitian. Langkah-langkah dari metodologi penelitian yaitu sebagai berikut :

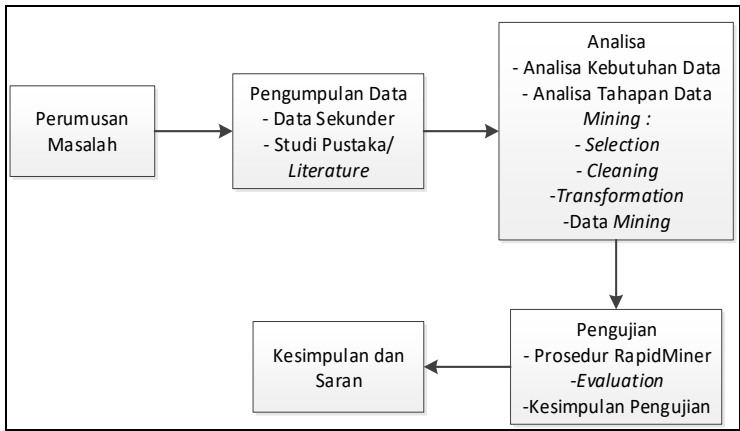

Gambar 3. Tahapan metodologi penelitian

\section{ANALISA}

Analisa merupakan suatu tahapan dimana dilakukan pembahasan untuk memahami permasalahan apa saja yang dihadapi dalam penelitian yang dilakukan. Dengan adanya tahapan analisa ini maka inti permasalahan yang ada dapat dijelaskan secara detail dan dapat dipelajari secara mendalam sehingga akan dapat dipahami dengan baik.

Data yang didapat dari Badan Lingkungan Hidup Kota Pekanbaru yaitu data dari tahun 2009 hingga 2015 dimana terdapat total berjumlah 16 variabel dan tiap variabel mempunyai record data setiap 30 menit.

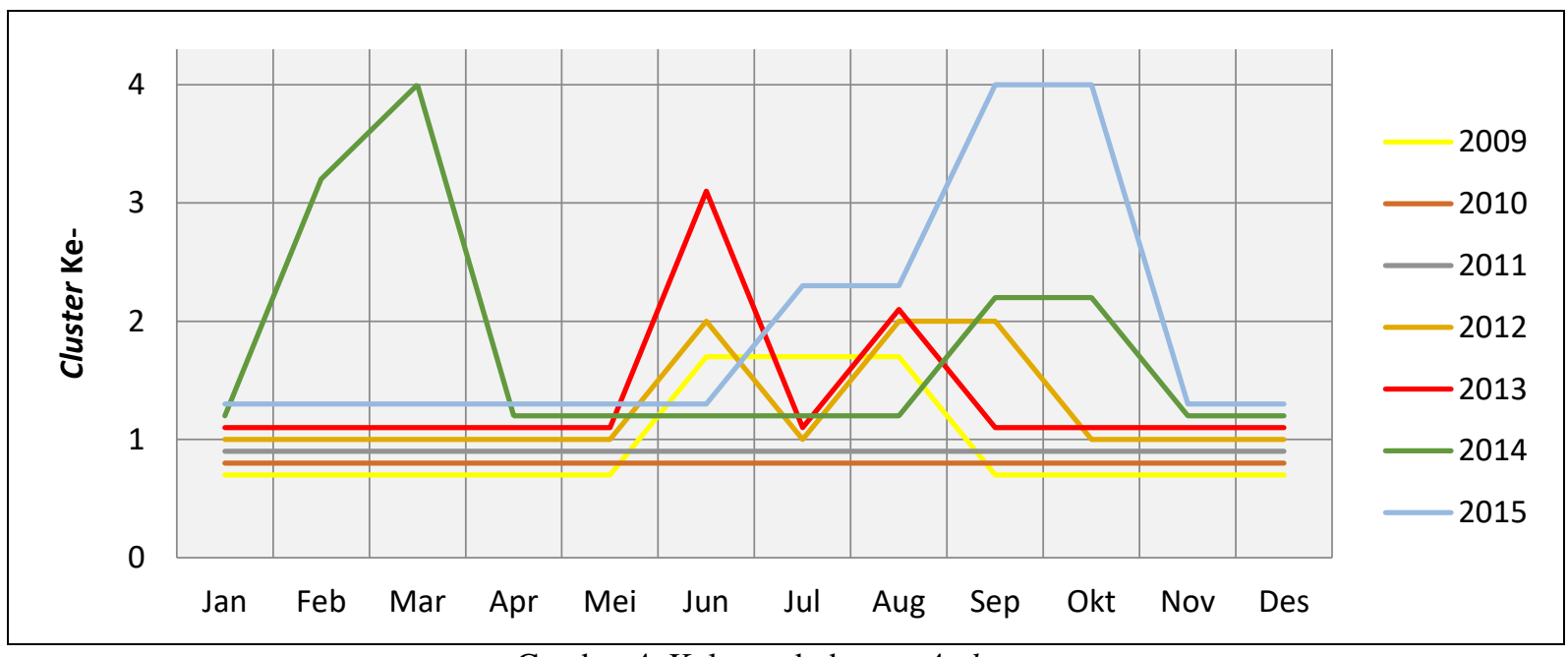

Gambar 4. Kelompok dengan 4 cluster

Dari jumlah total 16 variabel data yang tersedia, yang digunakan untuk penelitian yaitu data dengan variabel $\mathrm{PM}_{10}$ dari tahun 2009 hingga tahun 2015 dimana tiap variabelnya mempunyai record data setiap 30 menit. Sehingga total jumlah data hari yaitu sebanyak 2.556 hari dan jika data polutan di record setiap 30 menit setiap harinya maka jumlah keseluruhan data polutan udara yaitu 122.688 record data.



Gambar 5. Data variabel $\mathrm{PM}_{10}, \mathrm{SO}_{2}, \mathrm{CO}, \mathrm{O}_{3}, \mathrm{NO}_{2}$, NO

Setelah memilih data variabel $\mathrm{PM}_{10}$ dari tahun 2009 - 2015 kemudian di ambil rata-rata data variabel gas polutan per harinya. Data hasil dari tahapan Selection kemudian dilakukan pengecekan untuk mencari data yang masih mengandung missing 
value. Data polutan udara yang memiliki missing value dapat disebabkan oleh beberapa hal seperti maintenance rutin, kalibrasi alat, gangguan teknis, anomali kerja alat, mati lampu dan sebagainya. Proses cleaning dari data yang memiliki missing value yaitu dengan menginputkan data rata-rata tiap variabel perbulan kedalam data yang memiliki missing value. Jumlah data polutan udara yang memiliki missing value dari tahun 2009-2015 berjumlah 397 record dari 122.688 record data. Setelah semua data yang memiliki missing value hilang barulah menghitung rata-rata tiap variabel per bulan yang akan di jadikan data masukan untuk menghitung kelompok cluster menggunakan metode $K$-means clustering yang akan di cari pada aplikasi Rapidminer 5.3.

Berdasarkan dari data variabel yang telah didapatkan setelah melalui beberapa proses sebelumnya maka selanjutnya implementasi dari data variabel tersebut kedalam metode yang digunakan yaitu $K$-means untuk mendapatkan kelompok cluster yang di inginkan seperti yang telah di rencanakan sebelumnya.

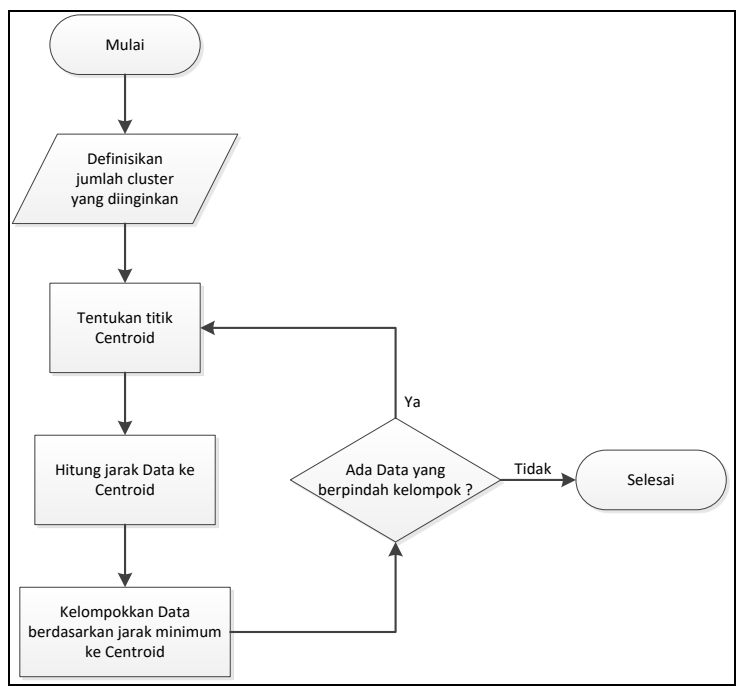

Gambar 6. Diagram alir metode $K$-means

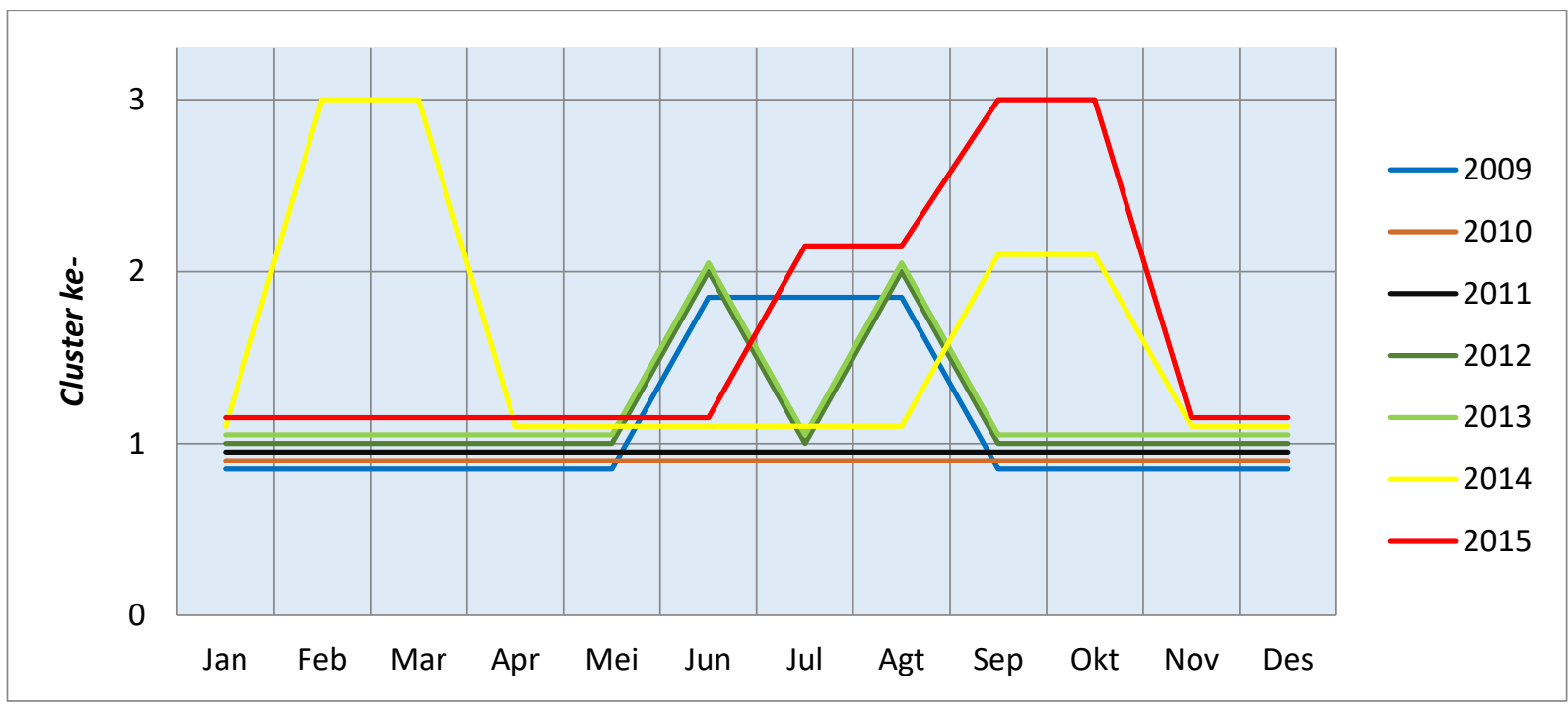

Gambar 7. Kelompok dengan 3 cluster

\section{PENGUJIAN}

Pengujian pertama dilakukan dengan mengujikan data polutan PM10 dengan menentukan cluster sebanyak 5 cluster dimana jumlah sebanyak 5 cluster berdasarkan jumlah kategori udara pada perhitungan Indeks Standar Polutan Udara. Hasil pengujian sebanyak 5 cluster dapat dilihat pada Gambar 4, dari hasil pengujian 5 cluster dapat dilihat bahwa cluster 1 merupakan kelompok dengan volume polutan antara 0 hingga 28,9. Cluster 2 merupakan kelompok dengan volume polutan antara 30 hingga 52,4. Cluster 3 merupakan kelompok dengan volume polutan antara 58,3 hingga 100,2. Cluster 4 merupakan kelompok dengan volume polutan antara 130,5 hingga 174,8. Cluster 5 merupakan kelompok dengan volume polutan antara 247,1 hingga 310,3.

Pengujian selanjutnya dilakukan dengan jumlah cluster sebanyak 4 cluster dimana dengan menggunakan 4 cluster kelompok cluster yang terbentuk memiliki anggota dengan rentang volume polutan seperti pada Gambar 1 Pengaruh ISPU Untuk Setiap Parameter Pencemar. Dari hasil pengujian dengan meggunakan 4 cluster dapat dilihat bahwa cluster 1 merupakan kelompok dengan 
volume polutan antara 0 hingga 50 . Cluster 2 merupakan kelompok dengan volume polutan antara 50 hingga 100. Cluster 3 merupakan kelompok dengan volume polutan antara 100 hingga 200. Cluster 4 merupakan kelompok dengan volume polutan antara 200 hingga 300.

Pengujian selanjutnya dilakukan dengan jumlah cluster sebanyak 3 cluster sebagai perbandingan untuk melihat pola yang dihasilkan. Dari hasil pengujian dengan meggunakan 3 cluster dapat dilihat bahwa cluster 1 merupakan kelompok dengan volume polutan antara 0 hingga 52,4. Cluster 2 merupakan kelompok dengan volume polutan antara 58,3 hingga 130,5. Cluster 3 merupakan kelompok dengan volume polutan antara 174,8 hingga 310,3 .

\section{KESIMPULAN}

Berdasarkan hasil analisa dan juga pengujian yang telah dilakukan maka beberapa hal yang dapat disimpulkan adalah sebagai berikut :

1. Dari hasil penelitian diketahui bahwa terdapat 16 bulan dari 84 bulan dari tahun 2009 - 2015 yang memiliki kadar polutan $\mathrm{PM}_{10}$ yang termasuk ke dalam kategori sedang hingga sangat tidak sehat.

2. Dari hasil penelitian dapat dilihat bahwa ratarata volume polutan $\mathrm{PM}_{10}$ mengalami kenaikan dimulai pada bulan Juni, volume polutan ratarata turun kembali pada bulan Oktober dan November.

Berdasarkan hasil yang didapatkan, saran dari penulis untuk pengembangan dari penelitian ini selanjutnya adalah:

1. Penelitian selanjutnya dapat dikembangkan dengan mencari pengaruh antara polutan udara dengan suatu kondisi seperti pengaruh polutan udara terhadap suatu penyakit tertentu, pengaruh polutan udara terhadap pertumbuhan tanaman tertentu, dan kondisi lainnya.

2. Penelitian selanjutnya diharapkan dapat menggunakan metode yang berbeda dengan penelitian ini untuk mendapatkan hasil yang lebih optimal terutama dalam pengujian menggunakan data polutan udara sesudah normalisasi.

\section{REFERENSI}

[1] R. Field, "Indonesia's Dangerous Haze," 26 October 2015. [Online]. Available: http://www.policyforum.net/indonesiasdangerous-haze/0.
[2] M. Syukur, 21 Oktober 2015. [Online]. Available:

http://news.liputan6.com/read/2345710/paruparu-penuh-asap-bocah-di-riau-meninggal. [Diakses 8 Oktober 2016].

[3] B. Warsito, D. Ispriyanti dan H. Widayanti, "Clustering Data Pencemaran Udara Sektor Industri di Jawa Tengah Dengan Kohonen Neural Network,” Jurnal PRESIPITASI, 2008.

[4] A. Iizuka, S. Shirato, A. Mizukoshi, M. Noguchi, A. Yamasaki dan Y. Yanagisawa, "A Cluster Analysis of Constant Ambient Air Monitoring Data from the Kanto Region of Japan," International Journal of Environmental Research and Public Health, pp. 6844-6855, 2014.

[5] J. Han dan M. Kamber, Data Mining Concepts and Techniques Second Edition, San Francisco: Morgan Kaufmann, 2006.

[6] Asroni dan R. Adrian, "Penerapan Metode Kmeans Untuk Clustering Mahasiswa Berdasarkan Nilai Akademik Dengan Weka Interface Studi Kasus Pada Jurusan Teknik Informatika UMM Magelang," Jurnal Ilmiah Semesta Teknika, pp. 76-82, 2015. 